\title{
Technology Integration in Nursing Education: Its Implications to Colleges of Nursing in Western Visayas, Philippines
}

\author{
Mae Joy B. Penaflor-Espinosa \\ Woosong University, Daejeon, Republic of Korea \\ maejoyespinosa426@yahoo.com
}

\begin{abstract}
This research was conducted to determine the technology integration in nursing education and its implications to the Colleges of Nursing in Western Visayas, Philippines The study included selected six higher education institutions offering Bachelor of Science in Nursing. The respondents of the study were the Dean of the College of Nursing AudioVisual Resources (AVR) Director, Library Director, Nursing Arts Loboratory Coordinator, Nursing Faculty and the 218 Level IV Nursing Students. Based on the findings, the top five available technology resources and faclities utilized by the nursing faculty were laptop and computer, microsoft office, mierophone, soynd system, and multimedia projector. The extent of information and communication technology (ICT) skills and the extent of integration of technology resources and facilities of the nursing faculty in teaching and learning process were moderate. The result suggests that the nursing faculty are competent in ICT. The use of ICT wasfound to be useful in their teaching responsibility. If they use ICT with greater confidence, the more they can integrate technology in their instructional preparation, delivery, and evaluation. It was also found that the extent of beneft of integration of technology resources and facilities as experienced by the nursing students was moderate.There is a significant relationship between the extent of skills of nursing faculty in using the information communication technology (ICT) and extent of integrating technological resources and facilities in teaching and learning process.
\end{abstract}

Keywords: Teghnology Integ ation, ICT, Nursing Education, College of Nursing

\section{Introduction}

"If technology is to be truly effective, it must be carefully and thoughtfully woven into the entire fabric of the school and learning. Done right, it changes both the appearance and nature of education" (Baker, 2013, p.1).

Education through technology is the way of the future wherein the advancement of technology has a radical impact in nursing and nursing education. Technology integration in the classroom and clinical instructions has become an important aspect of successful teaching. Technology has many benefits, but there is a huge gap in technology a ailability of resources and facilities, accessibility of training in nursing education as well as challenges on the high turnover of technology used in teaching and learning spheres.

Within nursing education, there is a need to integrate technology where the curriculum consists of an overwhelming amount of essential learning material wherein the student must have the advanced knowledge and critical thinking skills necessary to act with accuracy in life-and-death situations. Despite such promise, however, there is limited evidence regarding the integration of technology in nursing education.

Integrating information-communication technologies in teaching and learning is high on the educational reform agenda of developed and developing countries in which the evolving information technology era has become a major challenge for higher education 
institutions. In essence, nursing faculty must be prepared to use available resources and facilities, have access to needed support, and develop competency for using them throughout the curricula. Nursing faculty need to prepare students not only to become clinicians to promote health and improve well-being, but they must also instill the foundations of nursing education. To attain these, there is a need to redesign the nursing curriculum as technology, science, and the demands of the public for a more effective health care, become more complex. With today's current information explosion, it is also vital for the faculty to effectively engage today's contemporary learners in the classroom. Technological innovation and nursing education must respond in measured and carefully executed ways if it is to be relevant (Turale, 2011).

In the Philippines, integration of technology in the teaching-learning process has taken a lot of turns, and there has been a change of paradigm for the better. Technology experts of the school have started shifting gears, from being the "untouchable nerds" in the computer laboratory, into assistants who help teachers find better ways to bring technology at the service of learning (Matulac, 2004).

The researcher has observed that the use of information-communication tech ologies has been very limited. Its applications appear to be insufficient to ensure congruence with contemporary technological and educational principles and methôds of preparing students for the realities of modern healthcare contexts. Still in its infancy, these observations highlight the necessity to investigate the nature of the integration of technology in the teaching and learning process in nursing education. Locally only few studies have explored about the integration of technology in education. These dearths of literatures validate therefore the need of further and in-depth investigation of technology integration in local setting, specifically in nursing education. Thus, this study endeavors to examine how extensively the technology been integrated in nursing education and its implications to the Colleges of Nursing in Western Visayas, Phitippines.

\section{Methodology}

\subsection{Study Design}

This is a descriptive-correlational research that employed a one-shot survey design. David (2005) defined descriptive research as a type of study finding answer to the question who, what, when, where, and how. It describes a situation or a simple state of affairs in terms of specified aspects or factors. Moreover, relational analysis sometimes known as association research measures the extent or magnitude of association between two variables.

\subsection{Respondents}

The study included selected higher education institutions offering Bachelor of Science in Nursing in Western Visayas, Philippines. There are six nursing schools included, three of the nursing schools were taken from the Province of Negros Occidental and the three others were taken from the Province of Iloilo. These six nursing schools were included as the op performing nursing schools in the nursing licensure examinations in 2013 and 2014. Respondents of the study regarding the available resources and facilities for the College of Nursing included the Dean of the College of Nursing, Audio-Visual Resources (AVR) Director, Library Director, and Nursing Arts Laboratory Coordinator. The respondents on the utilization and integration of available resources and facilities in the College of Nursing are all Nursing Faculty and the 218 level IV Nursing Students. Table 1 show the sample distribution of the level IV nursing students. 


\section{Table 1. Distribution of Level 4 Nursing Students in Selected Nursing} Schools in Western Visayas, Philippines

\begin{tabular}{l|c|c}
\hline Colleges of Nursing & $\begin{array}{c}\text { Total Number of } \\
\text { Level 4 Nursing } \\
\text { Students }\end{array}$ & $\begin{array}{c}\text { Total } \\
\text { Number of } \\
\text { Respondents }\end{array}$ \\
\hline College A & 65 & 30 \\
College B & 81 & 37 \\
College C & 49 & 22 \\
College D & 45 & 20 \\
College E & 156 & 38 \\
College F & 479 \\
Total &
\end{tabular}

The study used a researcher-made questionnaire composed of four parts. Part I contains information about the profile of the college of nursing such as the total number of student population, the total number of nursing faculty and accreditation status for academic year 2014-2015. This was accomplished by the dean of the college of nursing. Part II enumerates the available technology resources and acilities for the college of nursing which was accomplished by the audio-visual resource director, library director, and nursing arts laboratory coordinator. Part III gathers data from the nursing faculty. This includes the profile of the nursing faculty suen age, sex, area of teaching assignment, years of teaching in the present institution. The checklist inquires on the available technology resources and facilities which have been utilized of the nursing faculty, extent of skill of nursing faculty in using information communication technology (ICT), and extent of integration of technology resources and facilities of the nursing faculty in teaching-learnm process. Part IV of the research instrument was the information gathered from the nursing students. This part contains information measuring extent of benefits of integration by the faculty in the teaching and learning process.

\section{Data Analysis}

Data gathered were processed and analyzed using the Statistical Package for Social Sciences (SPSS) version 17. Frequency distribution and means were used to analyze descriptive data while the Spearman's rho was used to determine the relationship between major variables.

\section{Results and Discussions}

\subsection{The Profile of the Colleges of Nursing}

The profile of the Colleges of Nursing in Western Visayas depicted the following information such as the total number of student population, total number of nursing faculty, and accreditation status. The data on the total number of student population reveal that there were 524 nursing students in College F, which is more than three times higher than the populations of Colleges $B(n=164)$ and $E(n=156)$. College D has 369 students, which is a higher than the populations of Colleges $\mathrm{C}$ and $\mathrm{A}$ ( $\mathrm{n}=341$ and 198, respectively). 
College $\mathrm{F}$ had the highest numbered of nursing faculty members while Colleges D, C, and $\mathrm{E}$ had about the same number of faculty members. Colleges A and B had the least numbered faculty members ( $n=24$ and $n=14$, respectively). The data on the accreditation status of nursing schools reveal that only College $\mathrm{F}$ has a Level IV accredited status. Colleges B, C, and D have Level II accreditation status, Colleges A and E have only Level I accreditation status.

There is a downward trend in the number of enrollees wherein the rate of nursing enrollment in Western Visayas is slowly plummeting in the past few years. As observed, the quantity of Filipino nursing graduates, however, has been inversely proportional to the quality of nursing education provided by the nursing schools. Many nursing schools have sprouted to meet the suddenly exploding demand for nurses, wherein many of those could not meet government standard, because there was a glut of nurses looking for jobs in both local and international markets. This phenomenon became more eminent when in December 2010, the Nursing Licensure Examinations had the lowest passing rate ever recorded in the history of the said examinations. Beyond that, the time might have finally come to change directions, so incoming college freshmen were advised to look at other directions, such as courses in fields related to environment and the sciences. It may be painful to accept that a wholesale paradigm shift may be requiled, but there is also, a need to understand that the landscape for the Filipino Nurse has changed a lol, perhaps for good (Philippine Regulations Commission, 2010). It was observed that the highest number of enrollees were in the College F, which is a government funded institution, while the five others were private educational schools. The major difference between public and private universities or colleges lies in how they are funded, and this will affect students because funding is tied to tuition fees. This is so because state universities are subsidized by the government and the money raised rom tuition does not need to cover all the expenses of a public institution. The low tuition and fees in the public schools attracts more students to enroll (II) public schools. Private colleges, however, do not receive subsidies from state legislatures whecen, they rely heavily on tuition and private contribution, that is why the tuition rates are generally higher.

The College of Nursing should have strong clinical faculty workforce who have appropriate academic preparation and specialization aligned the course/s he or she is teaching. Their roles and responsibilities must be closely tied to the central functions of higher education. Hence, the challenges greatly depend on the ability and preparedness of the faculty to organize the learning experiences in the classroom or various health situations based on the clearly-defined objectives. Accreditation ensures a basic level of quality in the education received from an institution. Being an accredited nursing institution is an affimation that the college provides quality of nursing education that the educational community recognizes. True to its commitment to continually strive for excellence and adhere to quality standards, the six nursing schools in Western Visayas have submitted to voluntary accreditation. The focus of accreditation includes the following areas: instruction and extension, research, performance in licensure examinations, faculty development, and linkages. If a school obtains a rating higher than (he minimum requirements of the Commission on Higher Education (CHED), then it can be deduced that it meets the standards of quality education and offers high quality learning opportunities for nursing students. 
Table 2. Profile of the Colleges of Nursing

\begin{tabular}{l|c|c|c|c}
\hline $\begin{array}{c}\text { Colleges of } \\
\text { Nursing }\end{array}$ & $\begin{array}{c}\text { Students } \\
\text { Population }\end{array}$ & $\begin{array}{c}\text { Number of } \\
\text { Nursing Faculty }\end{array}$ & $\begin{array}{c}\text { Number of } \\
\text { Nursing Faculty } \\
\text { Respondents }\end{array}$ & $\begin{array}{c}\text { Accreditation } \\
\text { Status }\end{array}$ \\
\hline College A & 198 & 24 & 24 & PAASCU-Level 1 \\
College B & 164 & 14 & 14 & PAASCU-Level 2 \\
College C & 341 & 32 & 21 & PAASCU-Level 2 \\
College D & 369 & 34 & 31 & PAASCU-Level 2 \\
College E & 156 & 36 & 36 & PACOCOA- \\
College F & 524 & 44 & 41 & Level 1 \\
& & & 167 & AACUP-Level 4 \\
Total & $\mathbf{1 7 5 2}$ & $\mathbf{1 7 9}$ & & \\
\hline
\end{tabular}

\subsection{The Profile of the Faculty in the Colleges of Nursing}

The data on age reveal the same proportion of the nursing faculty of the Colleges $\mathrm{B}$ (57.1\%) and $\mathrm{C}(57.1 \%)$ who were between 41 and 50 years old. The rest of the faculty of Colleges D (51.6\%) and A (45.8\%) were above 51 years old. Moreover, more than onethird of the faculty of Colleges E (38.9\%) and F (34.1\%) were between 31 and 40 years old. It is interesting to note that, of the six schools of nursing, only Colleges F (17.1\%), E $(8.3 \%)$, and C (9.5\%) had nursing faculty aged 26 to30 yearsold. Data on the age of the nursing faculty reveal that a majority of them are not digital natives, they are digital immigrants and their world view is different from the digital learners of this generation. In all, about $38.9 \%$ of the nursing faculties in the six nursing schools were 41-50 years old. The nursing faculty were aged 31 to 40 years old and 51 years old and above $(28.1 \%$ and $25.7 \%$, percent, respectively), while $7.2 \%$ of them were $26-30$ years old. The mean age is 44.87 years. These nurses seek stability in their nursing faculty position wherein most individuals in this age beacket would prioritize their family and elderly parents and respond to their needs.

The data on sex show that greater proportion of the faculty in the six colleges of nursing were-females (College $\mathrm{D}=100 \%$; College $\mathrm{A}=95.8 \%$; College $\mathrm{B}=92.9 \%$; College $\mathrm{C}=90.5 \%$; College $\mathrm{E}=77 \mathrm{8} \%$; and College $\mathrm{F}=68.3 \%$ ). Among the male faculty, less than one-third was recorded in Colleges F $(31.7 \%)$ and $\mathrm{E}(22.2 \%)$. There were only 1-2 male faculty found in the Colleges C, B, and A $(9.5 \%, 7.1 \%$, and $4.2 \%$, respectively), while none in College D. Females nurses $(85.0 \%)$ outnumbered the males by $70 \%$. The figures show that nursing faculty is still predominantly female profession because of its caring nature and maternal instinct, despite the influx of many males who have chosen this profession in the last two decades. Significant challenges to schools of nursing must be undeptaken to recruit nurses to faculty positions in an effort to have gender diversity mong the faculty.

The data on teaching assignment reveal that the entire faculty of College B (100\%) was assigned both in the classroom and clinical areas. A higher proportion of nursing faculty was assigned both in the classroom and clinical areas for Colleges E (91.7\%), F (78.0\%), A $(66.7 \%)$, and C (57.1\%), while less than one-half of them were in College D (41.9\%). In terms of those who were assigned in the clinical area only, more than half (51.6\%) were found to College D, while there were more than one-fifth in Colleges $\mathrm{C}(28.6 \%), \mathrm{F}$ $(22.0 \%)$, and A (20.8\%), none in Colleges B and E. The data also depict that only few of the nursing faculty in Colleges $\mathrm{C}, \mathrm{A}, \mathrm{E}$, and $\mathrm{D}(\mathrm{C}=14.3 \% ; \mathrm{A}=12.5 \% ; \mathrm{E}=8.3 \%$; and $\mathrm{D}=6.5 \%$, respectively) were assigned as classroom teachers only, but, none in Colleges $\mathrm{B}$ and $\mathrm{F}$. 
On the whole, there is higher proportion of nursing faculty who were assigned both in the classroom and clinical areas (71.9\%), while only few were assigned solely in the clinical area $(21.6 \%)$ or in the classroom (6.6\%). Part of the roles and responsibilities of a nurse faculty is to balance all dimensions of the role of being assigned in both classroom and clinical area. In this way, students get the benefit of maximum integration and learning from the expertise of nursing faculty. It is expected that the college of nursing must have a strong clinical teaching workforce.The majority of the nursing faculty has been teaching for 6 to 10 years (43.1\%), followed by those with 11 to 15 years of teaching experience $(32.3 \%)$ and those with 16 or more years of service $(14.4 \%)$. This reflects a cognizable blend of experiences from the institution they served wherein the more years of experience they have, the better it will create an atmosphere of familiarity and stability for curriculum development and implementation.

Table 3. Profile of the Faculty in the Colleges of Nursing

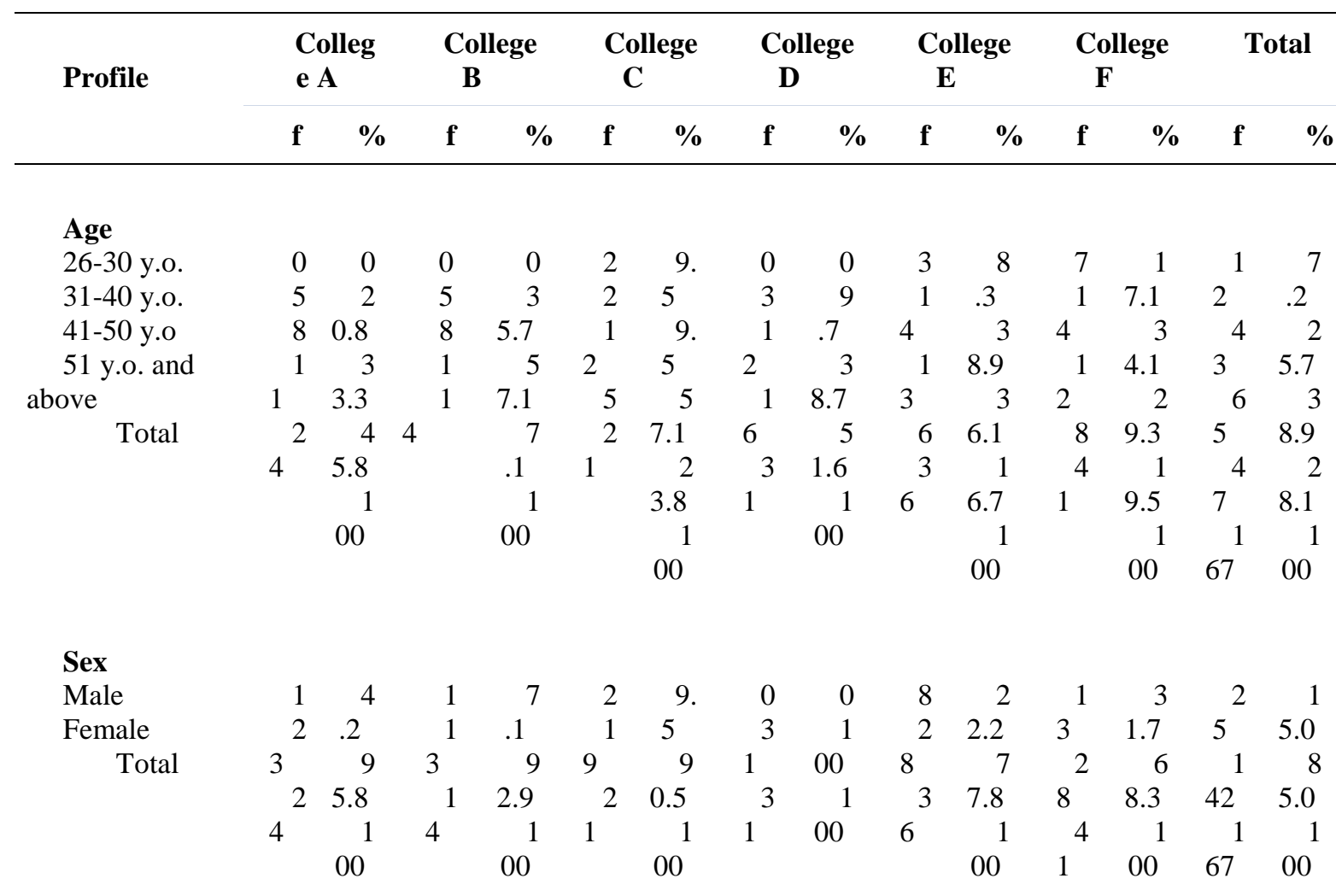

\begin{tabular}{|c|c|c|c|c|c|c|c|c|c|c|c|c|c|c|}
\hline Classroom & 2 & 1 & 0 & 0 & 3 & 1 & 2 & 6 & 3 & 8 & 0 & 0 & 1 & 6 \\
\hline Chical Area & 5 & 2.5 & 0 & 0 & 6 & 4.3 & 1 & .5 & 0 & .3 & 9 & 2 & 1 & .6 \\
\hline Classroom & 1 & 2 & 1 & 1 & 1 & 2 & 6 & 5 & 3 & 0 & 3 & 2.0 & 3 & 2 \\
\hline and Clinical & 6 & 0.8 & 4 & 00 & 2 & 8.6 & 1 & 1.6 & 3 & 9 & 2 & 7 & 6 & 1.6 \\
\hline Area & & 6 & & & & 5 & 3 & 4 & & 1.7 & & 8.0 & 1 & 7 \\
\hline \multirow[t]{3}{*}{ Total } & 2 & 6.7 & 1 & 1 & 2 & 7.1 & & 1.9 & 3 & & 4 & & 20 & 1.9 \\
\hline & 4 & & 4 & 00 & 1 & & 3 & & 6 & 1 & 1 & 1 & & \\
\hline & & 1 & & & & 1 & 1 & 1 & & 00 & & 00 & 1 & 1 \\
\hline
\end{tabular}




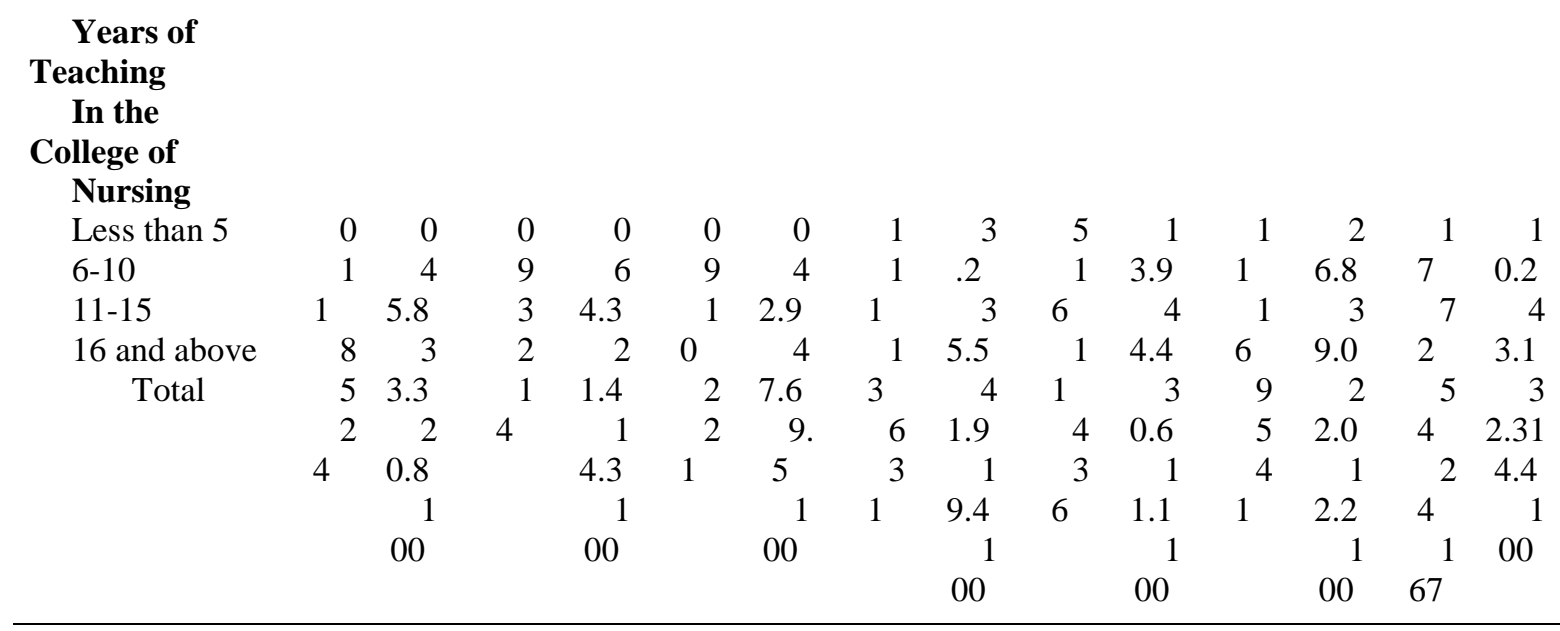

\subsection{The Available Technology Resources and Facilities for the Colleges of Nursing}

Table 5 shows the availability of technology resources and facilities for the college of nursing in terms of equipment, internet, and software ap lications.

In terms of equipment, laptops/computers, multimedia projectors, wide screen with stand, televisions, microphones, sound systems, and video camera are available for use in all colleges of nursing. Of the six, two have simulation laboratories and one has avermedia. It was also noted that all of the colleges have low fidelity nursing models, on the other hand, however, none have high fidelity nursing models. The data on internet like emails, world wide web, and webcasting were available for use in all colleges. Chat rooms were available in five colleges, except to College $\mathrm{F}$, and podcasting (module classes) which is only available o College $\mathrm{C}$. Furthermore, software/application like PROQUEST, Microsoft office (Word, Excel, Power Point, and Publisher), SPSS (Statistical Package for Social Sciences), image manipulating software (photoshop), content control software) OPAC (Online Public Access Catalogue), and videoconferencing were available in all Colleges of Nursing, while E-library was available only in College A.Technology in teaching and learning is an important and challenging aspect in higher education. Technology, in one form or another, has always been part of the teaching and learning environment especially in nursing education. It is part of the nursing faculty's professional toolbox. In other words, it is among the resources that they use to help facilitate student learning. It is evident that all colleges of nursing strive to get updated with the available technology resources and facilities. They aid in the implementation of various strategies, methods, activities in the teaching, and learning process. This is in response to the present trends and demands of the millennial learners that are digital based and text savvy. The classroom is no longer a boring scenario with traditional lecture and discussion rather learners are exposed to information gathered through the net and audio-visual techniques and surely amazed them. This is the enidence of a changing educational process of the $21^{\text {st }}$ century. 


\section{Table 4. Available Technology Resources and Facilities for the Colleges of Nursing}

\begin{tabular}{|c|c|c|c|c|c|c|}
\hline $\begin{array}{l}\text { Technology Resources } \\
\text { \& Facilities }\end{array}$ & $\begin{array}{l}\text { Colle } \\
\text { ge A }\end{array}$ & $\begin{array}{l}\text { Colle } \\
\text { ge B }\end{array}$ & $\begin{array}{l}\text { Colle } \\
\text { ge C }\end{array}$ & $\begin{array}{l}\text { Colle } \\
\text { ge D }\end{array}$ & $\begin{array}{l}\text { Colle } \\
\text { ge E }\end{array}$ & $\begin{array}{l}\text { Colle } \\
\text { ge F }\end{array}$ \\
\hline \multicolumn{7}{|l|}{ Equipment } \\
\hline Laptop/Computer & / & l & / & / & l & / \\
\hline Overhead & / & / & / & l & l & / \\
\hline Multimedia Projector & / & / & / & / & l & l \\
\hline Wide Screen with Stand & / & / & / & l & l & l \\
\hline Television & / & / & / & / & l & l \\
\hline Microphone & / & / & / & l & l & l \\
\hline Sound System & / & / & / & l & l & l \\
\hline Video Camera & / & / & / & l & I & l \\
\hline Simulation Laboratory & $\mathrm{x}$ & l & / & $\mathrm{x}$ & & $\mathrm{x}$ \\
\hline High Fidelity Models & $\mathrm{x}$ & $\mathrm{x}$ & $\mathrm{x}$ & $\mathrm{x}$ & & $\mathrm{x}$ \\
\hline Low-Fidelity Models & / & / & / & & l & / \\
\hline Avermedia & $\mathrm{x}$ & $\mathrm{x}$ & $\mathrm{x}$ & & $\mathrm{x}$ & l \\
\hline \multicolumn{7}{|l|}{ Internet } \\
\hline Emails & l & & & & l & / \\
\hline Chat Rooms & / & & & & / & $\mathrm{x}$ \\
\hline World Wide Web & / & & & l & / & l \\
\hline Webcasting (via Skype, YM or & / & & & / & l & / \\
\hline Hotmail Messenger) & & & & & & \\
\hline Podcasting (Module Classes) & & $\mathrm{x}$ & & $\mathrm{x}$ & $\mathrm{x}$ & $\mathrm{x}$ \\
\hline \multicolumn{7}{|l|}{ Software/Applications } \\
\hline PROQUEST & & & / & l & / & l \\
\hline E-Library & & & $\mathrm{x}$ & $\mathrm{x}$ & $\mathrm{x}$ & $\mathrm{x}$ \\
\hline Microsoft Office(Word & / & / & / & l & l & l \\
\hline Power point, and Publisher) & & & & & & \\
\hline SPSS (Statistical Packag & & l & / & l & l & l \\
\hline Social Sciences) & & & & & & \\
\hline Image Manipulating Soltware & & / & / & l & / & l \\
\hline (Photoshop) & & & & & & \\
\hline Content Control Software & / & / & / & / & / & / \\
\hline OPAC (Online Public & / & / & / & l & / & l \\
\hline Catalogue) & / & / & / & l & l & l \\
\hline
\end{tabular}

\subsection{The Extent of Uninzation of Available Technology Resources and Facilities of the Nursing Faculty}

The figures reveal that laptop and computer $(\mathrm{M}=3.70)$ had high utilization among the nursing faculty, while, multimedia projector $(M=3.20)$, microphone $(M=2.80)$, and sound system (2.80) had moderate utilization. On the other hand, wide screen with stand (2.60), simalation laboratory (2.10), low fidelity models (2.00), television (2.0), video camera (1.80) and overhead projector (1.80) were noted to have minimal utilization.

In terms of internet, emails $(M=3.20)$ and world wide web $(M=3.00)$ have moderate utilization, while there was only minimal utilization of chat rooms $(\mathrm{M}=2.20)$ and webcasting $(\mathrm{M}=2.00)$. With regards to software and applications, microsoft office $(M=3.60)$ such as word, excel, powerpoint, and publisher have been highly utilized by the nursing faculty. Content control software, SPSS (Statistical Package for Social Sciences), PROQUEST, image manipulating software (Photoshop), and OPAC have been used at a minimal level $(2.40,2.10,2.00,1.90$, and 1.90 , respectively).The lowest mean score was noted for videoconferencing (1.70). 
It is commendable those nursing faculties are comfortable in using the available technology resources and facilities. This suggests that technology is used in a regular basis with a variety of tools to create a dynamic classroom and clinical area learning process and understanding of content. Although other tools like overhead projector, television, video camera may seemed to be obsolete in a multimedia classroom where projection through the LCD can be achieved. Acquisition of low-fidelity models may require budgetary allocation from the administration. With the trend of decrease in nursing student population, budget as to be carefully allocated to be more priority needs for the college status.

Given the extent of utilization of technology resources and facilities among the nurse educators, it is useful to apply the tenets of Diffusion Theory (1995, cited by Sahin, 2006) to better understand the innovativeness of the faculty members in applying these technology resources and facilities in teaching and learning process. Diffusion theory provides a framework that helps the teacher to understand the importance of innovation in teaching. The diffusion theory can explain, predict, and account for factors thatincrease diffusion of innovation and utilization of technology resources and facilities can use. .

The result is supported by Adeoye and Popoola (2011) among the schools of nursing in Osun and Oyo States in Nigeria found that the available library informanton resources like computers/laptop, internet and CD-ROM facilities, and e-library were highly used by the nursing faculty. Furthermore, on the factors related to technology integration in instruction by Reedman, Kotrlik, and Douglas (2003) found that over one-half of marketing education teachers had email accounts while smaller number had interactive CDs, and layer disc player or stand alone players. Singth and Chan (2014) and Moganashwari and Parilah (2013), also confirms the research findings that the respondents were highly knowledgeable only of ertain applications such as word processing and internet browsing. Similar findings was noted in the study of Gorder (2008) in which the common applycations include word processing, internet browsers, presentation software, digital cameras/scaniers and graphics program were the most commonly used technology software by teachers in the classroom. On the other hand, however, the least usedechnology software were video conferencing, web-based collaboration programs, and blogs/weblogs/podcasts/wikipedia.

Effective teaching incorporates using a variety of teaching methods and the creation of opportunities for the students to deyelop critical thinking and reasoning skills. Laptop and computer and microsoft office scored highest among the utilized technologies by the nursing faculty to enhance leaching practices and efficiency, and they agreed that the use of these technologies post tively influenced student learning, and have changed the way they work.

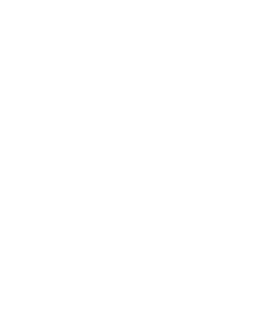




\section{Table 5. Extent of Utilization of Available Technology Resources and Facilities of the Nursing Faculty}

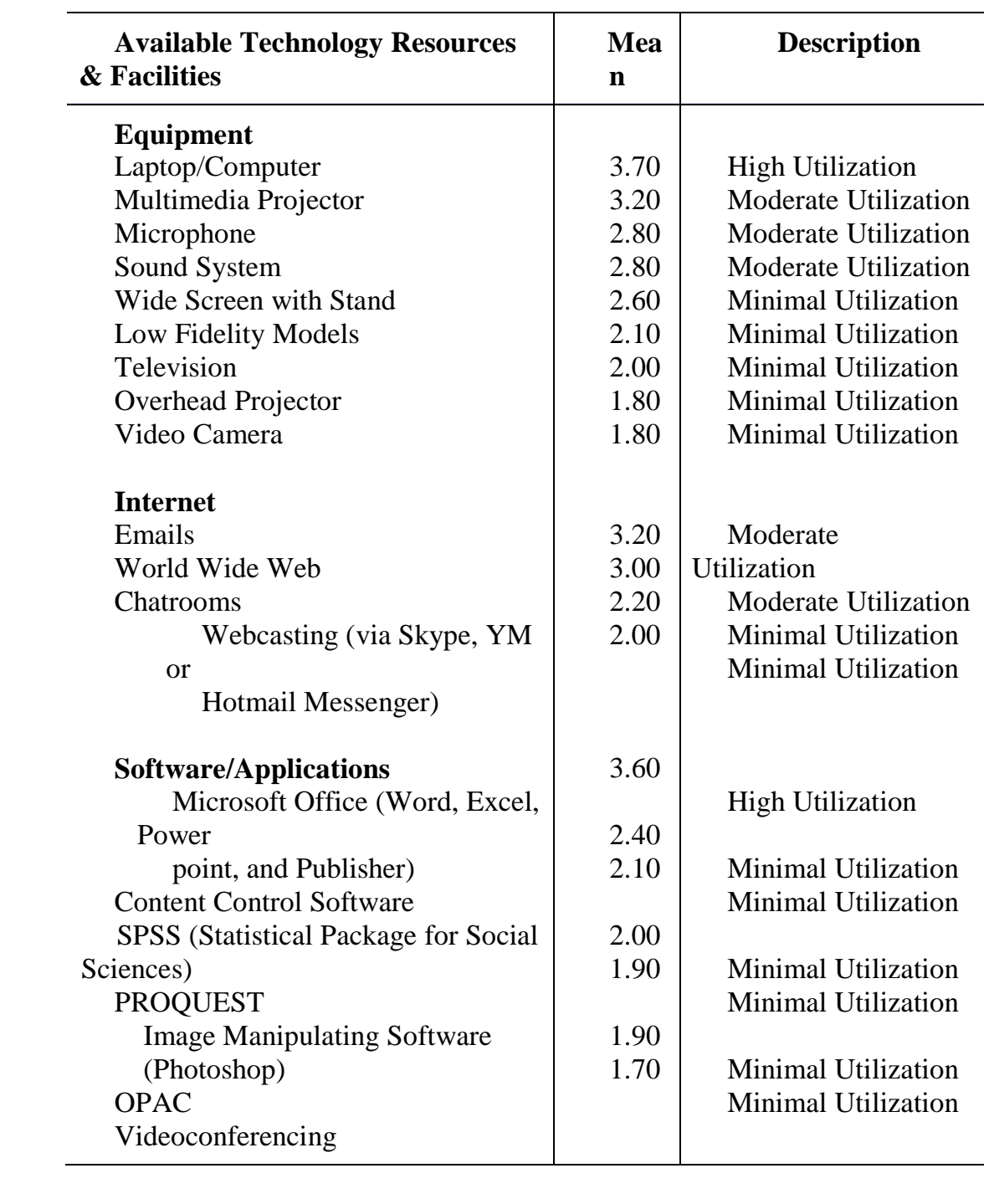

\subsection{The Extent of the Information Communication Technology (ICT) Skills of the Nursing Faculty}

The data on the ICT skills of the nursing faculty in all colleges of nursing were highly skilled in starting, setting-up, and closing of digital-based technologies ( $M=3.62,3.51$, respectively. However, moderately skilled in setting-up of sound system $(\mathrm{M}=3.46)$. It was also found that they were highly skilled in receiving, manipulating and responding to digital data through text messaging $(\mathrm{M}=3.74)$, emails $(\mathrm{M}=3.58)$, and social networking $(\mathrm{M}=3.51)$.Exploring of web engines were high $(\mathrm{M}=3.55)$, however, video sharing was moderate $(\mathrm{M}=3.23)$.

The results of this study are consistent with the findings of Redmann, Kotrlik, and Douglas (2003) which showed that the marketing education teachers are strongest in exploration and adoption phases of the technology integration model for regular use in instruction.

In terms of utilization and sharing of digital data, the study revealed that the respondents were highly skilled in microsoft word $(\mathrm{M}=3.51)$, and presentation software $(\mathrm{M}=3.50)$ through writing of letters and reports, and making of presentations. Furthermore, they have moderate skills in the use of spreadsheets like Microsoft excel $(M=3.36)$ through computing and analyzing of grades, searching related literature and 
studies through PROQUEST and EBSCO ( $\mathrm{M}=2.97)$, desktop publishing $(\mathrm{M}=2.86)$ through adobe design, and graphic software $(\mathrm{M}=2.73)$ through creation and editing of images, logo, drawings, and pictures.

The over-all ICT skills of the nursing faculty in the six colleges of nursing were moderately skilled in using information and communication technology. This means that they have workable knowledge of their skills, however, they need more practice to be fully confident in the use of their technology skills. Furthermore, an intervention program for technology integration in nursing education will prove beneficial for all stakeholders, school administration, nursing faculty, nursing students.

The constructivism (Ozer, 2004) finds appropriate application in explaining the link between ICT skills and integration when done with the correct approach. This approach is to maintain a constructivist classroom by supporting higher order of thinking skills, and by making any learning connectable to the real life situation of the given students. The key to making this successful is that the nursing faculty whether in the classroom of in the clinical area, should learn and practice on the use of the technology and integrate it with commitment to students learning. The result is supported by the findings of Gorde (2008) which reported that teachers have agreed most strongly that they perform basic file management tasks, operate common technology, that they use software productivity tools, and that they use technology to locate, evaluate, and collect educational research. Similar findings were reported by Bauer and Kenton (2005) which revealed that the teachers in their study were highly educated and highly skilled with technology and were innovative and adept at overcoming obstacles in using technology in the classroom. Furthermore, Alazam, Bakar, Hamzah, and Asmiran (2012) revealed in theinstudy that the level of ICT skills among technical and vocational teachers were moderate. The ICT skills consisted of seven groups of skills in this study, AutoCAD software, followed by skills of world wide web, skills of computer-aided design and draf(ing (CADD), skills of microsoft excel, skills of digital video and animatyon, skills of programming languages and skills of simulation.

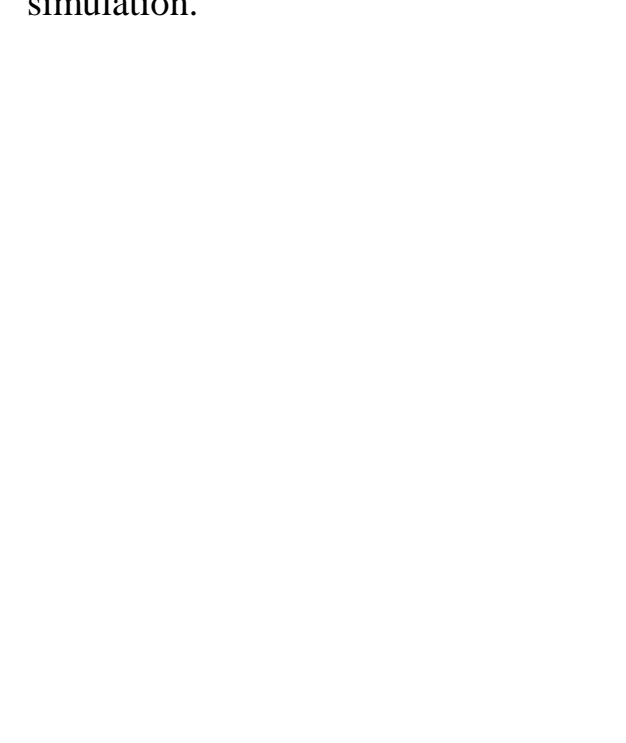




\section{Table 6. Extent of the Information Communication Technology (ICT) Skills of the Nursing Faculty}

Information Communication Technology
(ICT) Skills

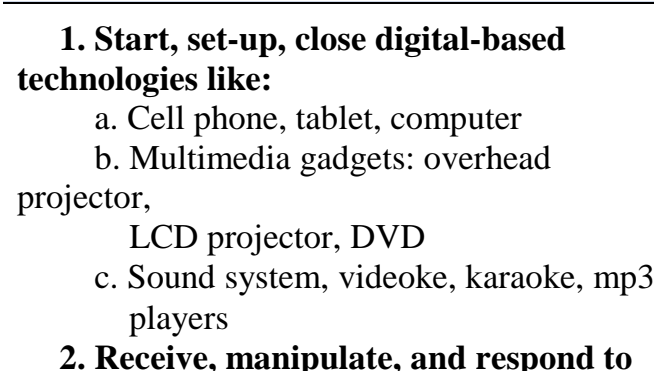
digital data thru:
a. Text message
b. Social networking like Facebook, Twitter, and Instagram
c. Emails

3. Explore, receive, store digital data thru: webs

a. Search engines like google, search

b. Video sharing like youtube thru:

a. Word processing: e.g. Microsoft word:write letters and reports

b. Database software e. $g$ Proquest, EBSCO: search related literature and studies

c. Presentation Software: e.g Microsoft PowerPoint make presentations

d. Spreadsheets: e.g. Microsoft Excel: compute and analyze grades Desktop Publishing. e.g. Adobe Design, Mcrosoft Publisher Graphic Sortware: e.g. Adobe Photoshop and Illustrates: create and dit images, logos, drawings and pictures Overall ICT Skills
3.62 Highly skilled
$3.51 \quad$ Highly skilled
$3.46 \quad$ Moderately skilled

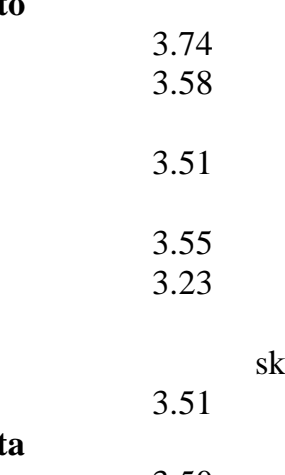
Highly skilled skilled Highly skinled Highly skilled Moderately killed

Highly skilled Highly skilled 3.36 2.97 Moderately skilled

2.86

2.73 skilled

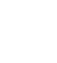

\subsection{The Extent of Integration of Technology Resources and Facilities by the Nursing Faculty in Teaching and Learning Process}

As presented in Table 7, the extent of integration of technology resources and facilities of the nursing faculty in the teaching and learning process reveal a moderate extent of integration. The results further show that in keeping and organizing of students' records, high extent of integration was reported in the preparation of teaching activities. The highest mean extent of integration scores was 3.79. The creating of instructional materials and lesson plans $(\mathrm{M}=3.67)$, in searching for online sources $(\mathrm{M}=3.57)$, and communicating and collaborating with peers, students, and their parents $(M=3.39)$ technology was also 
highly integrated in teaching activities. However, the respondents only moderately integrated technology in collecting and evaluating students' assignment and work $(\mathrm{M}=2.82)$ and in participating in online professional developmental activities $(\mathrm{M}=2.65)$. $\mathrm{T}$

In terms of instructional delivery, power point and multimedia preparations, in skills demonstration and training, and in simulations $(M=3.68)$ technology integration was high, but in remediation of students' learning deficits and in supporting of content knowledge and skills (drill, practice, tutorials) integration was moderate $(M=3.62$ and $M=2.62$, respectively). In terms of instructional evaluation, such as creation of presentations, writing paper or reports $(M=3.50)$ was highly integrated while having students practice drills, and problem solving $(\mathrm{M}=3.44)$, having students work on collaborative projects, and in the conduct of research $(\mathrm{M}=3.44)$, and having the students complete a computer-based tests $(M=2.67)$, extent of integration was moderate. The sub-mean in terms of instructional preparation, delivery, and evaluation show that the nursing faculty had moderate extent of integration of technology resources and facilities in the teaching and learning process $(\mathrm{M}=3.46,3.31$, and 3.26, respectively).

The Constructivist Theory (Ozer, 2004) takes a key role in technology-integration wherein one aspect of constructivism is social collaboration. Collaboration is a key in applying constructivist principle, whether the collaboration between teacher and student, or between students. The teacher provides the scaffolding and support for the students to acquire the appropriate skill. With the world wide web collaboration can occur online, where students view their peers as resources for support. In any classroom, each student brings different skills, including computer-based skills, and unique styles to the learning process. Each individual can support the unicue thinking and learning skills of another. Multimedia has the ability to cater indi idual preferences and support what can be described as constructivist pedagogy in a number of vays. The use of multimedia tools is entirely compatible with the open-ended, non-linear constructivist model of learning. The technology allows teachers and stadents to create interruptive, presentations and projects through integration of images, graphics texts, animation, audio and motion video. Learning is enhanced by communication, resulting in to new knowledge, re-organized knowledge or additional anderstanding with groups of students learning to use the tools of their culture in a collaborative learning environment.

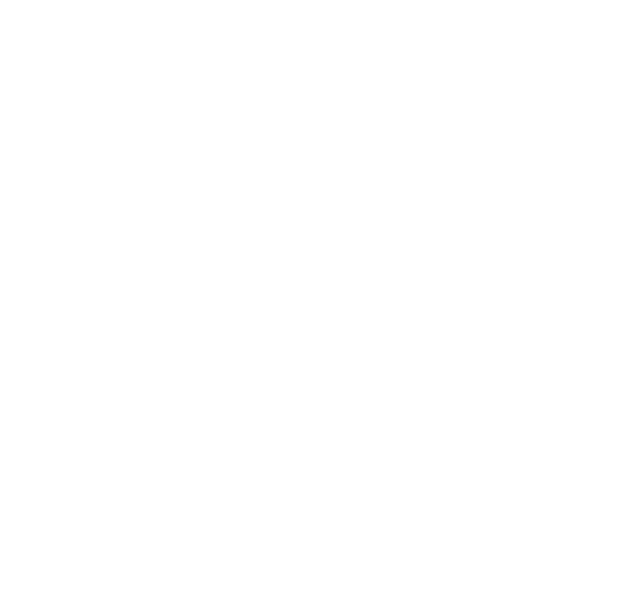




\section{Table 7. Extent of Integration of Technology Resources and Facilities of the} Nursing Facultyin the Teaching and Learning Process

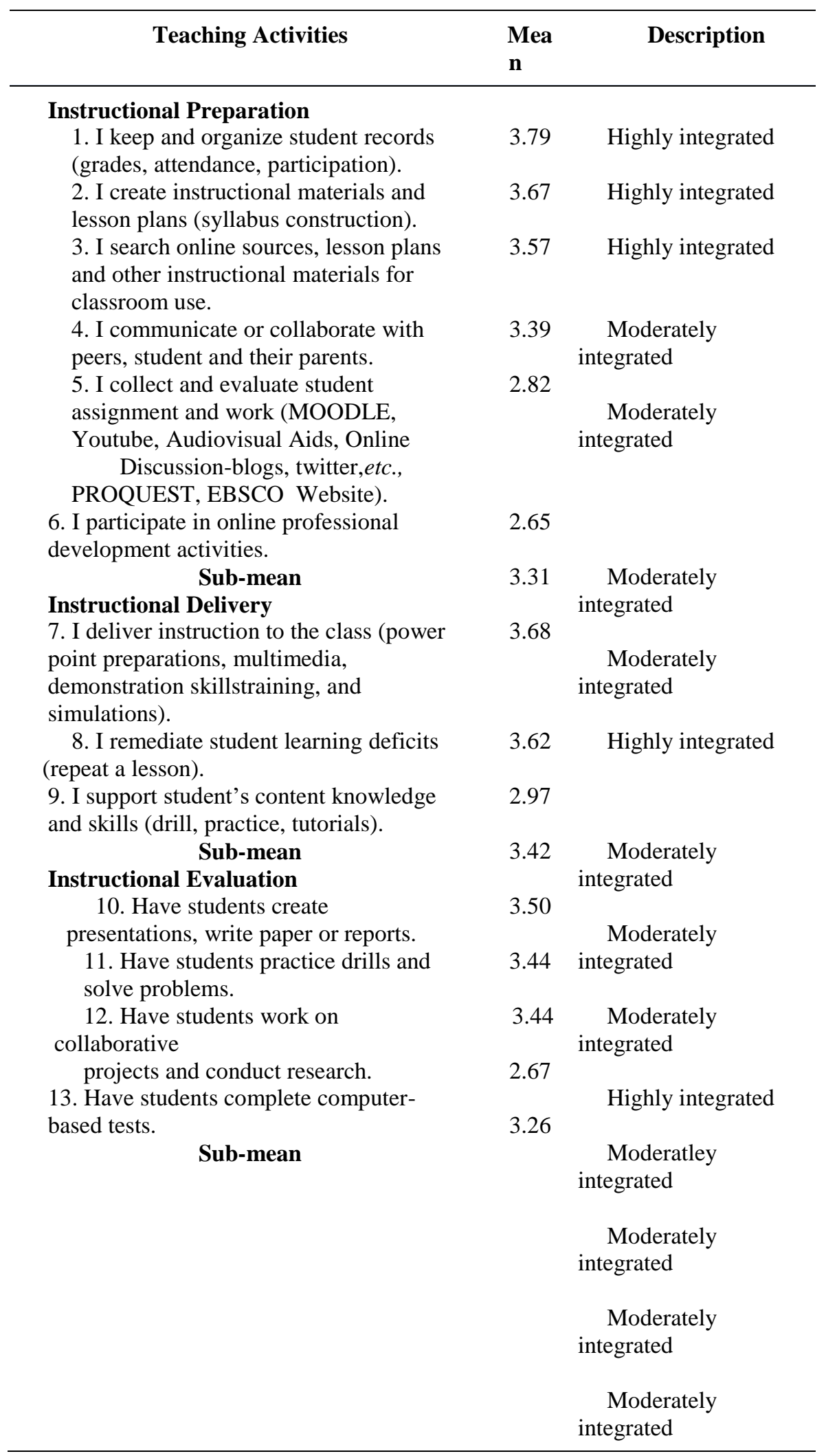


5.7. The Relationship between the Information Communication Technology (ICT) Skills and Extent of Integration of Technology Resources and Facilities of the Nursing Faculty in the Teaching and Learning Process

Table 8 shows the statistical data on the relationship between the teachers' information communication technology (ICT) skills and their extent of integration of technology resources and facilities in the teaching and learning process. The Spearman's rho value of 0.520 is significant $(\mathrm{p}=0.000)$. This indicates a positive and substantial significant relationship existed between the two variables. Therefore, the null hypothesis that the extent of information communication technology skills is not significantly correlated to extent of integration of technology resources and facilities by the nursing faculty is rejected. The result further indicates that the more skilled the faculty in using information and communication (ICT) the more likely they will integrate technology in their teaching and learning activities. The study implies that the higher the teachers' ICT skills are greater is the likelihood of an excellent integration of ICT in teaching and learning. Teachers should possess not only ICT knowledge and skills but they must also develop and imbibe right attitudes towards ICT.

The findings of this study are consistent with the results of previous researches and literature that explored teachers' ICT skills and integration into teaching and learning process. These studies pointed out that ICT skills of teachers (Rastogi and Malhotra, 2013; Alazam,Bakar, Hamzah, and Asmiran, 2012; Buabeng-Andoh, 2012; Agyei and Voogt, 2011; Inan and Lowther, 2010; Mahmud and Ismael, 2010) are significant related with extent of integrating ICT in teaching. The findings, however, is opposite those of the study by Russell, O'Dwyer, Bebell, and Tad (2007) which revealed no relationship between teachers' teaching experience and experience in the use of ICT. This implies that teacher's ICT skills and successful implementation is Complex and is not a clear predictor of ICT integration.

Table 8. Relationship between the Information Communication Technology

(ICT) Skills and Extent of Integration of Technology Resources and Facilities of the Nursing Faculty in the Teaching and Learning Process

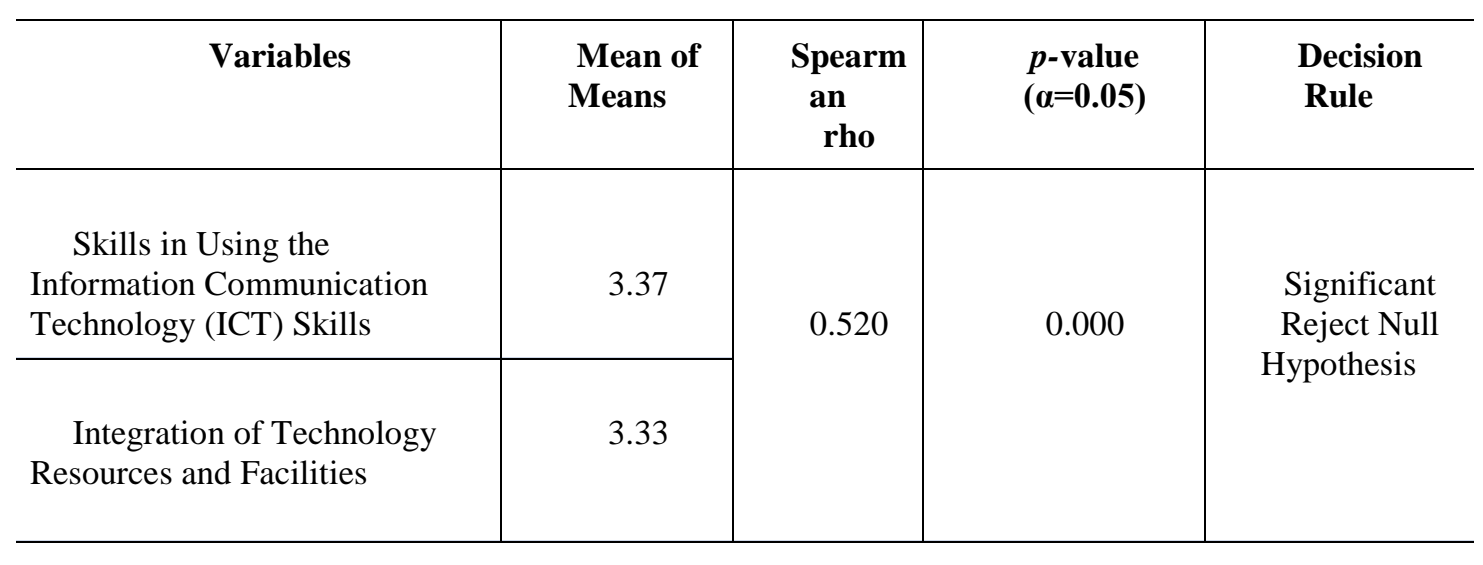

5.8. The Extent of Benefit of Integration of Technology Resources and Facilities of the Nursing Faculty in the Teaching and Learning Process as Experienced by the Nursing Students

The top three highly beneficial of technology integration in teaching and learning process as experienced by nursing students were making the students happy with their learning $(\mathrm{M}=3.58)$, helped in communication and collaboration $(\mathrm{M}=3.50)$ and allowed students to enjoy varied learning activities $(\mathrm{M}=3.48)$. The lowest mean scores, but were still equivalent to a moderately beneficial assessment were registered by the perception that technology has improved school-related requirements $(\mathrm{M}=3.49)$, enjoyed varied 
learning activities $(\mathrm{M}=3.48)$, motivated and attentive in class $(\mathrm{M}=3.39)$, and confident in new knowledge gained $(\mathrm{M}=3.39)$.

The over-all result show moderate extent of benefit of the integration of technology resources and facilities by the nursing faculty in teaching and learning process. This indicates that technology integration can increase students' motivation and foster positive attitude towards learning. Students in technology-enhanced classrooms are more likely to have enjoyable and meaningful learning experiences. This encourages students to look optimistically towards learning with technology and enhances their outcomes. Thus, technology integration in the teaching and learning benefits the students in numerous ways in their quest life-long learning.

\section{Table 9. Extent of Benefit of Integration of Technology Resources and Facilities of the Nursing Faculty in Teaching and Learning Process as Experienced by the Nursing Students}

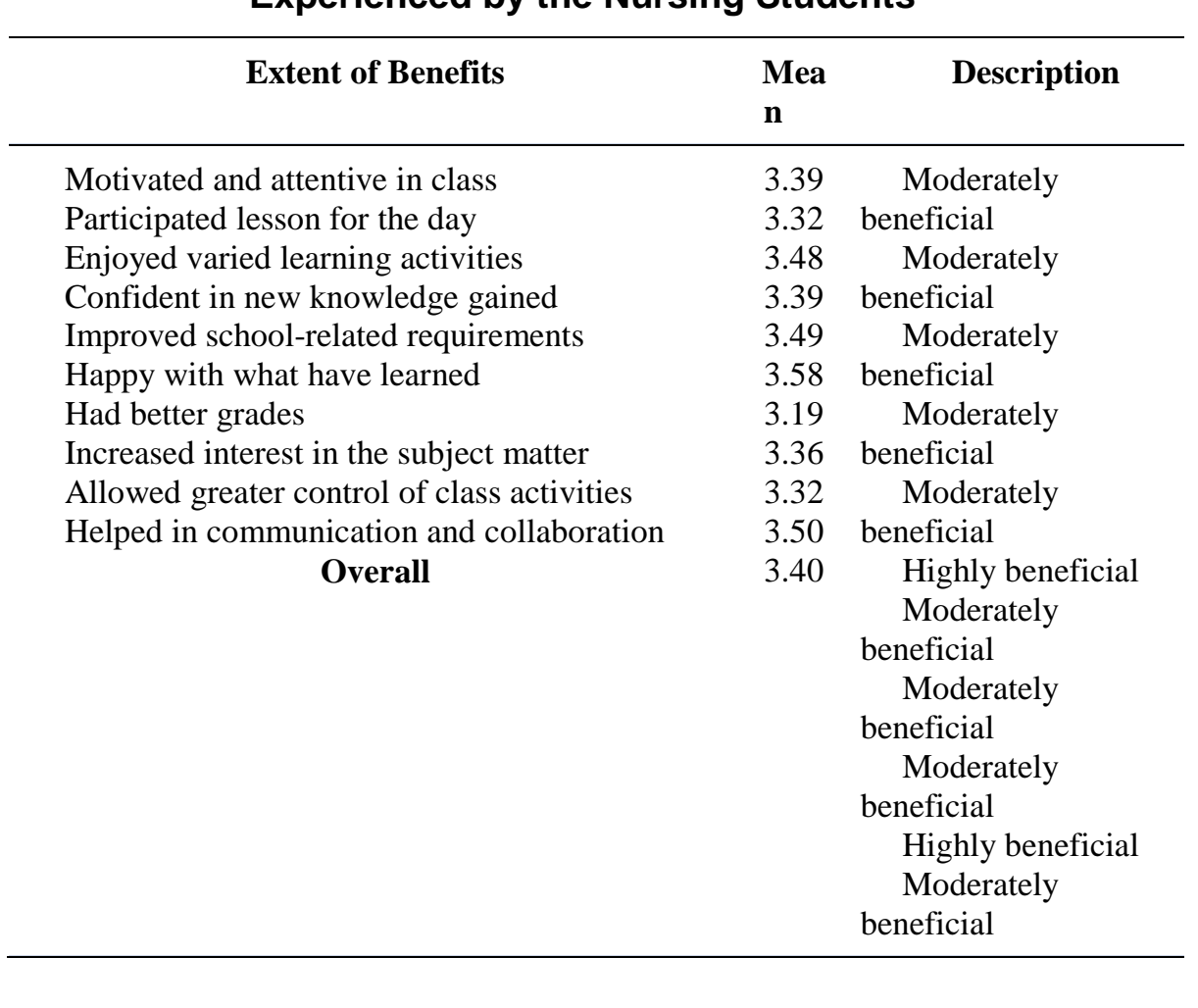

\section{Conclusion}

6.1 The nursing faculty members are competent in ICT. Obviously, they find the use of ICT to be-useful in their teaching responsibility. If they use ICT with greater confidence, the more they can integrate technology in their instructional preparation, delivery, and evaluation.

6.2 The understanding of integration here is constructed on the basis of analyses, to measure the availability and accessibility of equipment, infrastructure, software, and applications. Effective technology integration in colleges of nursing in Western Visayas can only be realized if technology resources and facilities are available. The effective use of these technologies to aid instruction both in the classroom and clinical area, particularly in engaging the students in online learning, blended classrooms, project based-activities incorporating technology, game-based learning and learning with mobile and hand-held devices have not yet been fully achieved or reached.

6.3 The research concludes that the integration of technology can make a measurable difference in teaching and in the learning process. Interactive, self-directed learning, and high order thinking can be fostered by technology, and that technology can have the 
greatest benefit when the environment is conducive to such experiences. This indicates that the benefits of technology integration do not happen in some miraculous way simply because the technology has been provided, and technology cannot be effective without teachers who are knowledgeable and skillful about both the technology itself and how to use it to meet educational goals.

6.4 Therefore, in order to accomplish the profound changes associated with the integration of technology in the overall learning environment and to enhance teaching and learning process, there is a real need for the administration to increase their enabling capacity to revise their vision and educational philosophy, resource capitalization, installation and provision of access to technological equipment, and feedback mechanisms on the impact of technology in education and the nursing faculty to develop their enhancing capability in using technology in educating their students (preparation, delivery, and evaluation) as evidenced by the presence of capability-building programs, creative lesson planning and blended learning, and adaptation to technological use.

6.5 The research evidence confirms that the constructivist learning environments and innovations, representing that learning with technology, which encourages-leamers to actively process and organize information by making internal cognitive connections, can well provide the theoretical framework for effective technology integration.

\section{References}

[1] S. Turale, "Technology and its impact in nursing education" Journal of Nursing Science, vol. 29, no. 1, (2011), pp. 9-17.

[2] M. Matulac, "Experiences in technology integration", IETs in Basiceducation. First National Congress. Retrieved January 1, 2015 from http://wwwsfited.org/íctcongress/paper/fullpapers/matulac.pdf.

[3] F. David, "Understanding and doing research. a handbook for beginners", Iloilo City: Panorama Printing, Inc., (2005).

[4] http://www.prc.gov.ph.

[5] I. Sahin, "Detailed review of Rogers affusion of innovations theory and educational technology-related studies based on Rogers' theory", The Turkish Onling Journal of Educational Technology, vol. 3, no. 2, (2006), pp. 14-23.

[6] M.O. Adeoye and S.O. Popoola, "Teaching effectiveness, availability, accessibility, and use of library and information resource among teaching staff of schools of nursing in Osun and Oyo State, Nigeria", Library Philosophy and Practice (ejournal), (2011).

[7] D.H. Redmann, J Kotrlik and B. Douglas, "Factors related to technology integration in instruction by marketing education teachers", Journal of Career and Technical Education, vol. 19, no. 2, (2003), pp. $29-46$.

[8] T.K. Singh and S. Chan, "Teachers readiness on ICT integration in teaching-

learning: a Maraysian case study, International Journal of Asian Social Science, vol. 4, no. 7, (2014), pp. 874-885.

[9] K. Moganashwari and M.S. Parilah, "Knowledge, attitude and use of ICT among ESL teachers", Proceeding of the Global Summit on Education, Kuala Lumpur. Organized by WorldConferences.net, (2013).

[10] L.M. Gorder, "A study of teacher perceptions of instructional technology integration in the classroom", The Delta Pi Epsilon Journal, vol. L, no. 2, (2008), pp. 63-76.

[11] O. Ozer, "Constructivism in Piaget and Vygotsky", Retrieved January2, 2015 from Ittp. /www.fountaininmagazine.com, (2004).

12) B. Bauer and J. Kenton, "Toward technology integration in the schools: Why it isn't happening", Journal f Technology and Teacher Education, vol. 13, no. 4, (2005), pp. 519-546.

[13] M. Zohrabi, "Mixed Method Research: Instruments, Validity, Reliability and Reporting Findings", Theory and Practice in Language Studies, vol. 3, no. 2, (2013), pp. 254-262.

[14] A. Alazam, A.R. Bakar, R. Hamzah and S. Asmiran, "Teachers ICT skills and ICT integration integration in the classroom: the case of vocational and technical teachers in Malaysia", ScIRP Journal 3, (2012), pp. 70-76.

[15] A. Rastogi and S. Malhotra, "ICT skills and attitude as determinants of ICT pedagody integration", European Academic Research, vol. 1, no. 2, (2012).

[16] C. Buabeng-Andoh, "Factors influencing teacher's adotiopn and integration of information and communication technology into teaching: a review of the literature", International Journal of Education and Development using Information and Communication Technology, vol. 8, no. 1, (2012), pp. 136-155.

[17] F. Inan and D. Lowther, "Factors affecting technology integration in K-12 classrooms: a path model", Educational Technology Research and Development, vol. 58, no. 2, (2010), pp. 137-154. 
[18] R. Mahmud and M.A.H Ismail, "Impact of training and experience in using ICT on in-service teachers' basic ICT literacy”, Malaysian Journal of Educational Technology, vol. 10, no. 2, (2010), pp. 1-10.

[19] M. Russell, L.M. O'Dwyer, D. Bebell and W. Tao, "How teachers' use of technology vary by tenure and longetivity", Journal of Educational Computing Research, vol. 37, no. 4, (2007), pp. 393-417.

\section{Author}

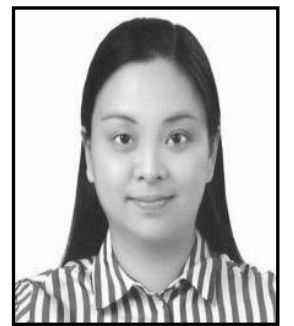

Mae Joy P. Espinosa, $\mathrm{PhD}, \mathrm{RN}$, she is an Assistant Professor in Woosong University, Daejeon, Republic of Korea. She had been a Lecturer in Sultan Qaboos University, College of Nursing, Oman Muscat. She has made significant contributions to patient care through teaching, lectures, leadership activities and professional activities both in graduate and undergraduate nursing.

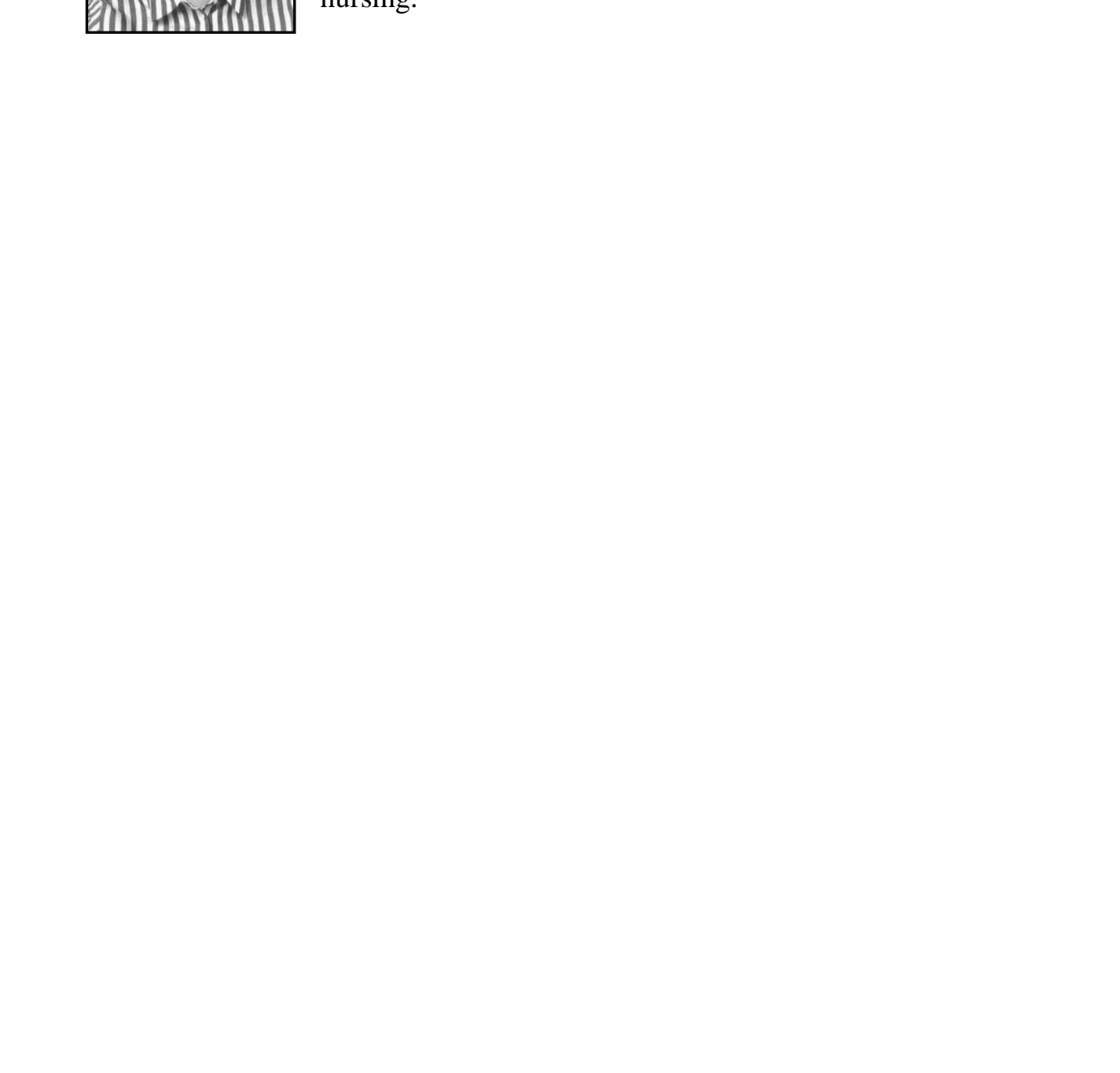

